\title{
PENERAPAN SISTEM MULITI LEVEL MARKETING (MLM) DI P.T ASURANSI ALLIANZ LIFE INDONESIA CABANG MANADO DI TINJAU DARI PERSFEKTIF HUKUM ISLAM
}

\author{
Oleh: Achmad Husain
}

\begin{abstract}
ABSTRAK
Penelitian ini berkenaan dengan studi penerapan hukum isalam yang bertujuan dalam pengaplikasain penerapan sistem multi level marketing (MLM) di P.T Asuransi Allianz life Indonesia asuransi syariah yang di pasarkan kepada masyarakat yang banyak di Negara kesatuan Republik Indonesia yang khususnya mayoritas penduduknya adalah pemeluk agama Islam dan pada umumnya di luar pemeluk agama Islam yang begitu bersimpati dengan prinsip ekonomi Islam (Syariah).Oleh karena itu, peneliti mencoba mengkaji bagaimana peranan Syariah dalam realitas kehidupan perekonomian di Indonesia, setelah ekonomi konvensional yang mengalami krisis moneter berapa tahun lalu, sehingga para pelaku-pelaku ekonomi mulai melirik ekonomi Islam (Syariah).
\end{abstract}

Jenis penelitian ini adalah deskriptif kualitaif dengan pendekatan studi kasus. Penelitian ini di laksanakan di P.T Asuransi Allianz Life Indonesia cabang manado sejak bulan Januari 2014 sampai bulan Maret 2014. Jenis penekatan yang di lakukan oleh peneliti yaitu pendekatan yudiris dan sosiologis dimana peneliti sebagai alat pengumpul data utama dengan melakukan beberapa teknik pengumpulan data yaitu observasi, wawancara kangsung dan staudi dokumentasi. Cara pengambilan sampel pada penelitian ini dengan cara memilih orang tertentu yang di pertimbangkan akan memberikan informasi yang di perlukan secara lengkap.

Pengelola syarat Islam harus dilakukan secara professional dan jelas. Hal ini bertujuan untuk meningkatkan kepercayaan para maysarakat atas dana yang di titipkan di sebuah lembaga keuangan non bank (Asuransi) yang menggunakan lebel syariah, yang telah mereka bayarkan dalam bentuk premi sampai kepada orang yang berhak menerima dana tersebut baik penanggung-tertanggung, serta prosedur klaim yang jelas. 


\section{A. PENDAHULUAN}

Kemajuan peradaban modern sekarang ini adalah buah dari kemajuan ilmu pengetahuan dan teknologi yang banyak menyebabkan manusia terjerumus dalam hidup serakah, dalam rangka memenuhi kebutuhan hidupnya dengan menghalalkan segala cara. Menonjolnya kemajuan aspek kebendaan dalam peradaban manusia menyebabkan terabaikannya aspek moral.Pola hidup modern yang timpang karna dominasi matrealistis, menjadi tantangan berat dalam kehidupan beragama yang konsisten dan murni.Menurut pandangan Islam kehidupan pisik materil membuat banyak manusia yang tidak istiqomah dengan pengamalan Islamnya.

Dalam kehidupan sehari-hari yang penuh dengan ketidakpastian, serta dalam dunia bisnis ini dikenal adanya resiko yang kemungkinan terbesar akan terjadi. Misalnya resiko kecelakaan lalu lintas, resiko kendaraan, pencurian, kapal tenggelam di tengah laut, resiko kematian dan sebagainya.Begitu banyak resiko, dan beratnya beban apabila resiko itu terjadi, maka munculah pengetahuan tentang manajemen resiko. Sebagai mahluk Allah, ketika tidak apa dan harus berusaha agar dapat menghindari resiko seminimal mungkin. Kita harus berusaha mengantisipasi, dan berjaga-jaga terhadap datangnya resiko.(H. Buchari Alam dan Donni Juni Priansa, 2009, 34).

Asuransi segabagai lembaga keuangan nonbank, terorganisir secara rapi dalam bentuk sebuah perusahaan yang berorientasi pada aspek bisnis telah kelihatan secaranyata pada era modern.(AM Hasan ALI, 2004, 6) Bersamaan dengan boomingnya semangat revolusi industri di kalangan masyarakat barat, banyak tuntutan untuk mengadakan sebuah langkah proteksi terhadap kegiatan atau aktivitas ekonomi, buruh pabrik misalnya, yang menjadi instrument dalam pertumbuhan industri merasa bahwa aktivitas di pabrik tidak hanya sekedar untuk kepentingan ekonomi tanpa resiko. Tetapi, sebaliknya meraka merasakan bahwa selama melakukan aktivitas di pabrik, keselamatan jiwanya benar-benar membutuhkan sebuah lembaga yang bisa memberikan proteksi terhadap jiwanya.Sehigga secara pisikologi, ketenangan dan ketentraman dapat menikmati selama melakukan aktivitas ekonominya, di samping resiko yang selama ini di khawatirkan dapat di hindari atau paling tidak diminimalisir menjadi sesuatu yang tidak memberatkan jika suatu hari nantinya mendapatkan kerugian dalam aktivitas ekonomi.Maka pilihan yang tepat terdapat pada institusi yang bernama asuransi. 
Pada hakikatnya, secara teoritis semangat semangat yang terkandung dalam sebuah lebaga asuransi tidak bisa di lepaskan dari semangat sosial dan saling tolong menolong antar sesame manusia.Secara historis, fenomena di atas sudah ada bersama dengan adanya manusia. Hal ini menguatkan sebuah buku tentang status manusia yang satu sisi sebagai makhluk individu dan di sisi lain dia juga merangkap sebagai manusia sosial yang tidak dapat melepaskan dirinya dari dari orang lain. Asuransi yang di dalamnya melibatkan kelompok sosial telah memberikan gambaran adanya bentuk pertanggungan antara anggota kelompok.

Paling tidak dalam kajian sejarah banyak aktifitas manusia dalam tempo dulu yang 'mirip' ataupun mempunyai unsur-unsur yang di miliki oleh sebuah lembaga asuransi. Pada masa Yunani kuno, Alexandria agung ( Iskandar Zulkarnain ) pernah meninstruksikan kotapraja untuk meminjam uang pada konglomerat-konglomerat masa itu, dan timbal baliknya kotapraja memberikan semacam penanggungan kepada pihak konglomerat jika suatu ketika mendapat musibah atau kerugian.

Di Romawi, di kenal dengan adanya perkumlupan kematian. Begitu pula dengan apa yang terjadi di masyarakt Arab Pra Islam. Mereka mengenalkan tradisi "iuran darah". Dimana semangat kesukuan masih kuat telah menjadi wahana dalam pelambangan praktik "iuran darah" dapat di gambarkan sebagai berikut: "jika salah satu anggota suku melakukan pembunuhan, maka secara hukum anggota tersebut juga bisa dibunuh oelh suku yang anggotanya sukunya terbunuh". Maka agar tidak tearjadi balas dendam antar suku, di carikan jalan lainnya, yaitu berupa "iuran darah" dimana kepala suku memerintahkan anggota sukunya (Aqilah) untuk melakukan iuran dalam bentuk pengumpulan hewan, untuk di jadikan diyatatau kompetisi yang akan di serahkan kepada suku yang anggotanya terbunuh. Pada masyarakat Arab sendiri terdapat sistem yang sudah menjadi kebiasaan mereka sejak masa pra-Islam. Aqilah merupakan cara penutuan (istilah yang digunakan oleh AM. Hasan Ali). ( AM. Hasan Ali, 2004, 62).

Dari gambaran tersebut, kata kunci yang melandasi semua aktivitas di atas adalah semangat gotong royong. Kebersamaan dan saking membantu diantara sesame inilah yang selanjutnya secara prinsip menjadi landasan utama bagi berlangsungnya sebuah lembaga asuransi. Pada tataran di atas, hokum islam melihat praktek asuransi masih dapat di terima, 
karena adanya unsur tolong menolong yang mengarah pada kebaikan, serta belum di ketemukannya unsur gharar, maysir ataupun dzulm didalamnya.

Kondisi di atas akan terlihat lain sewaktu asuransi memasuki era modern dan terlambangkan dalam sebuah institusi. Asuransi pada masa ini sudah tidak lagi beriorentasi secara murni (pure) terhadap semangat tolong-menolong, tetapi lebih dari itu lembaga asuransi telah mengubah dirinya segabai salah satu mesin ekonomi dunia modern, di samping lembaga perbankan.Hal ini merupakan konsekuensi logis dari diterapkanya paham kapitalisme dengan berbagai instrumen yang mendukungnya, seperti semangat liberalism dan idividuallisme, kondisi ini telah membawa perbedaan manusia pada situasi yang lebih mementingkan diri sendiri dan hanya sekedar mengejar kepentingan materialistic.

Asuransi telah terbelenggu dakam rantai kapitalis-materialis.Semangat tolong-menolong telah terpuruk dalam jurang keinstanan dan telah di ganti dengan keserakahan dan keangkaramurkaan oleh manusia-manusia yang yang otaknya telah dilumuri oleh semangat individualistik-materialistik.Gambling dan ke-zaliman telah menjadi warnya yang tidak dapat di pisahkan dalam operasional asuransi konvensiolan. Sebagai gambaran, seorang yang mengasuransikan rumahnya pada sebuah lembaga asuransi, dia akan di kenakan biaya asuransi dalam bentuk premi dalam jangka tertentu, dengan jumlah uang tertentu pula. Sebagai gantinya perusahaan asuransi akan mengluarkan polis bagi orang tersebut. Jika telah jatuh tempo dan peristiwa kerugian tidak terjadi, maka uang premi yang di bayarkan ke perusahaan asuransi itu dinyatakan hangus menjadi milik perusahaan.

\section{B. Rumusan Masalah dan Batasan masalahnya}

1. Bagaimana penerapan sistem multi level marketing MLM pada P.T Asuransi Allianz Life Indonesia?

2. Apakah sistem P.T Asuransi Allianz Life Indonesia yang di jalankan sudah sesuai dengan landasan hukum? 


\section{Larangan Transaksi Islam.}

\section{Riba (bunga)}

Islam mengangap riba (bunga) sebagai kejahatan ekonomi yang menimbulkan penderitaan masyarakat, baik ekonomi,sosial, dan moral. Dalam Alquran terdapat beberapa ayat yang menjelaskan larangan mendapatkan kekayaan secara bathil.Islam menghalalkan jual beli dan mengaharamkan riba.Riba di haramkan karena mendatangkan kezaliman dan ketidakadilan yang bertentangan dengan tujuan penetapan prinsip ekonomi Islam. Allah SWT berfirman dalam Al-Quran surat al-baqarah ayat 275;

Terjemahannya:

“orang-orang yang makan (mengambil) riba, tidak dapat berdiri melainkan seperti berdirinya orang yang kemasukan syaitan lantaran (tekanan) penyakit gila. Keadaan mereka yang demikian itu, adalah disebabkan mereka berkata (berpendapat), sesungguhnya jaul beli itu sama dengan riba, padahal Allah telah menghalalkan jual beli dan mengharamkan riba. Orang-orang yang telah sampai kepadanya larangan dari Tuhannya, lalu terus berhenti (dari mengambil riba), maka baginya apa yang telah di ambilnya dahulu ( sebelum datang larangan ); dan urusannya ( terserah) kepada Allah. Orang yang kembali ( mengambil riba), maka orang itu adalah penghuni-penghuni neraka; mereka kekal di dalamnya”.

Riba itu ada dua macam : nasiah dan fadhl. Riba nasiah ialah pembayaran lebih yan di syaratkan oleh orang yang meminjamkan.Riba fadhl ialah penukaran suatu barang dengan barang yang sejenis, tetapi lebih banyak jumlahnya karan orang yang menukarkan mensyaratkan demikian, seperti penukaran emas dengan emas, padi dengan padi, dan sebagainya.Riba yang di maksud dalam ayat ini. Riba nasiah yang berlipat ganda yang umum terjadi dalam masyarakat Arab zaman jahiliah maksudnya: orang yang mengambil riba tidak tentram jiwanya seperti orang kemasukan syaitan. Riba yang sudah di ambil (dipunggut) sebelum turun ayat ini, boleh tidak di kembaliakn. 


\section{Mayasir (perjudian, gambling)}

Asuransi syariah tidak mengandung unsur pertaruhan dan untung-untungan dilarang oleh Islam. Hal ini sebagaimana firman Allah SWT dalam Alquran surat al-Maaidah ayat 90;

Terjemahanya :

“hai orang orang yang beriman, sesungguhnya (meminum) khamar, berjudi, (berkorban untuk) berhala, mengundi nasib dengan panah, adalah termasuk perbuatan syaitan. Maka jauhilah perbuatan-perbuatan itu agar kamu mendapat keberuntungan.

\section{Dasar Hukum}

Selanjutnya dari kata hokum menyimpan makna yang luas yang meliputi semua peraturan atau ketentuan, baik tertulis maupun tak tertulis yang mengatur kehidupan masyarakat dan akan memberikan sanksi terhadap pelaanggarnya. Selanjutnya, apakah yang disebut hukum itu yang dalam Bahasa asing disebut recht (belanda), law (inggris) atau, ius (latin). Pada umumnya para ahli hukum memberikan definisi dipengaruhi oleh berbagai factor, antara lain tentang setting pengalaman yang selama ini dialami, penguasaan atau kedalaman pengetahuannya tentang hukum. Dengan demikian sulit rasanya menemukan definisi dalam bentuk rumusan yang singkat, padat, dan tegas sehingga memenuhi syarat jamik, artinya bisa memotret semua elemen yang seharusnya masuk kedalam pengertian.(Muhammad Djafar, 2009, 19)

\section{Landasan Hukum Islam}

Konsep hukum dalam ajaran Islam berada dengan konsep hukum pada umumnya, khususnya hukum moderen.Dalam Islam hukum di pandang sebagai bagian dari agama, dam norama-norama hukum bersumber kepada agama.Umat islammeyakini bahwa hukum Isalm berdasarkan kepada wahyu Ilahi.Oleh karana itu di sebut syariah. (Syamsul Anwar, 2007, 3).

Tujuan asuransi sangatlah mulia, karana bertujuan untuk tolong-menolong dalam kebaikan. Dalam Islam, asuransi haruslah bertujuan dalam konsep tolong-menolong dalam 
kebaikan dan ketaqwaan serta menjadikan semua aspek peserta sebagai keluarga besar yang saling menanggung satu sama lain.

\section{Landasan Hukum Positif}

Secara sturktural, landasan oprasional asuransi Syariah di Indonesia masih menginduk pada peraturan yang mengatur usaha perasuransian secara umum (Konvensioanl). Baru ada peraturan secara tegas menjelaskan asuransi Syariah pada surat keputusan Direktur Jendral lembaga keuangan (DJLK) No. Kep.4499/LK/2000 tentang jenis, penilaian dan pembatasan investasi Perusahaan asuransi dan Perusahaan Reasuransi dengan sistem Syariah.

1. UU No.2 Tahun 1992 tentang usaha perasuransian

2. Peraturan pemerintah No. 63 Tahun 1999 tentang Perubahan atas peraturan Pemerintah No. 73 Tahun 1992

3. UU No. 1 Tahun 1995 tentang Perseroan terbatas

4. Keputusan Dewan Syariah Nasional No. 02 Tahun 2000 tentang petunjuk dan pelaksanaan penetapan Anggota Dewan Pengasuh syariah pada Lembaga Keuangan Syariah.

\section{E. Teori-teori Pembiyayaan Umum}

Menurut Soekarno, biyaya adalah harag perolehan yang di korabankan atau di gunakan dalam rangka memperoleh penghasilan atau revenue yang akan di pakai sebagai pengurangan penghasilan. Menurut Djohanputro, pengertian dasar resiko terkait dengan keadaan adanya ketidakpastian dan tingkat ketidapastiannya terukur secara Kuantitatif. Risiko juga dapat di artikan sebagai ketidakpastiaan yang telah di ketahui tingkat probabilitas kejadiannya.

Untuk menghitung besarnya premi risiko atau biyaya risiko dapat di rumuskan sebagai berikut:

Biaya Risiko = PPAP yang wajib di bentuk x 100\% Aktifa Produktif. (Peraturan Bank Indonesia) 


\section{Pembiyayaan Bagi Hasil}

Pembiyayaan bagi hasil merupakan pembiyayaan modal kerja dan investasi.Modal kerja meliputi uang tunai, barang, jasa.Pada pembiyayaan investasi maka posisi pembiyayaan identikdengan ekuitas. Artinya pokok pembiyayaan bisa tidak di angsur pada priode perhitungan dan distribusi bagi hasil melainkan bisa pada akhir priode sesuai dengan kesepakatan yang tidak menzolimi salah satu pihak.

Menurut standart akutansi.(PSAK, No 105 Akutansi Mudharabah, paragraph 11) dasar perhitungan bagi hasil adalah laba kotor atau laba oprasional atau laba bersih. Dasar penentuan bagi hasil adalah nisbah (porsi) antara LKS dan nasabah dari laba tersebut.Secara konspesi nisabh ini di tentukan pada saat akad dan proporsinya tetap selama priode akad yang telah di sepakati. (Muhammad Nazarul Alim, 2011, 85-86)

Rumus bagi hasil

Bagi hasil $=$ modal $-($ Biaya Oprasional + Biaya Produksi $)$

Biasanya yang terjadi pada bagi hasil langsung pada profitnya (keutntungan), bukan pada omset penjualan.

\section{F. Teori Bisnis Pemasaran Berjenjang}

Pemasaran berjejang adalah sebuah model bisnis yang sudah tidak berkelanjutan yang melibatkan pembayaran peserta menjanjikan atau jasa, terutama untuk mendaftarkan orang lain kedalam skema, daripada memasok setiap investasi riil atau penjualan produk atau jasa kepada masyarakat. Berbagi bentuk skema piramida adalah illegal dibanyak negara termasuk (Amerika Utara, Amerika Serikat dan kanada) Eropa barat (Austria, Belanda, Belgia, Denmark, Portugal Swedia dan Swiss) dan Asia Timur ( Jepang dan Korea Selatan). Jenis skkema sudah ada sekiranya sejak satu abad, beberapa dengan varerasi untuk menyembunyikan sifat asli mereka. Banyak orang menganggap semua multi level marketing berencana untuk menjadi skema piramida. Keanggotaan di dalam multi level marketing merupakan salah satu inti dari sistem pemasaran. 
Pemasaran berjenjang ( Bahasa Inggris: Multi Level Marketing) adalah sistem penjualan yang memanfaatkan konsumen sebagai tenaga penyalur secara langsung. Sistem permainan uang cenderung menggunakan skema piramida (Skema Ponzi ) dan orang yang terakhir bergabung akan kesulitan mengembangkan bisisnya. Dalam pemasaran berjenjang, walaupun di mungkinkan telah memiliki banayk bawahan, tapi tanpa omzet tentu saja bonus tidak akan di peroleh.

\section{G. Teori Marketing}

Secara substantive pemasaran stratejik memiliki perbedan dalam bebrapa aspek seperti kerangka waktu, proses keputusan, hubungan dengan lingkungan dan lainnya.Aspek waktu dari menejemen pemasaran bersifat jangka pendek dan keputusan yang di ambil berkaitan dengan waktu tertentu, proses keputusan, cenderung top-dawon, serta lingkungan di anggap konstan.Sedangkan pemasaran stratejik bersifat jangka panjang dan keputusan yang di ambil memiliki implikasi jangka panjang, proses keputusan cenderung bottom-up serta lingkungan di anggap sering berudah dan dinamis.

Cravens dan Piercy mengemukakan bahwa pemasaram stratejik merupakan proses market-driven dari pengembangan strategi yang mempertimbangkan perubahan lingkungan dan kebutuhan untuk menawarkan superior customer value. Fokus dari pemasaran stratejik yaitu dari kinerja organisasi. Dalam hal ini, pemasaran strategi menghubungkan organisasi dengan lingkungan serta memandang pemasaran sebagai suatu fungsi yang memiliki tanggung jawab melebihi fungsi lain dalam keseluruhan aktivitas bisnis. (Keegan, Warren J., 1996, 84)

\section{H. Track Record Perusahaan Allianz}

\section{Allianz Grup}

Allianz merupakan salah satu perusahaan global terbesar yang bergerak di bidang layanan asuransi dan menejemen asset, Allianz berdiri pada tahun 1980 di Jerman dan merupakan perusahaan yang sangat berpengalaman dan mempunyai posisi finansial yang kuat.(www.Allianz.com) 
Saat ini Allianz beroprasi di lebih dari 70 Negara di seluruh dunia dan melayani lebih dari 78 juta nasabah di seluruh dunia.Allianz memberikan perlindungan dan pelayanan kepada nasabah tersebut termasuk dalam kategori perusahaan Fortune 500.

\section{Allianz Asia Pasifik}

Asia Pasifik adalah satu dari tiga kawasan yang tumbuh pesat di Dunia.Dengan kekayaan budaya, Bahasa dan adat istiadat yang beraneka ragam sebagai karakterristik dari regional ini. Allianz hadir di Asia Pasifik pada yahun 1917, di pesisir Cina dengan menyediakan asuransi kebakaran dan asuransi jasa pengangkutan

Di Asia Pasifik, Allianz hadir di 14 pasar dengan focus utama pada bisnis asuransi umum, jiwa dan kesehatan, dan manajemen asset. Dengan lebih dari 14,500 staf, Allianz melayani kebutuhan lebih dari 21,5 juta nasabah di kawasan ini. Keampuan Allianz untuk beradaptasi dengan cepat terhadap kebutuhan local menjadi kunci sukses.

Allianz meneruskan ke suksesan di Asia pada enam bulan pertama tahun 2013. Totsl pendapatan mencatat pertumbuhan sebanyak 4,9\% menjadi 3,8 miliar euro, dari 3,7 miliar euro di priode yang sama tahun lalu. Laba oprasionaln naik hingga 34\% menjadi 289 juta euro dari 215 juta euro selama priode tersebut.

\section{Pendapat Ulama dan Tokoh-Tokoh Islam}

Dewan raharjo, tokoh Islam dari Muammadiyah yang juga di kenal sebagai Pembina sosial ekonomi DPP Muhammadiyah mengemukakan, dalam Islam sistem pemasaran MLM tidak haram hukumnya. Bahkan sistem pemasaran bisnis MLM cukup baik dan adil. Catatan Redaksi INFO APLI, ini masih cukup punya relevansi sehubungan dengan adanya isu haram/halal terhadap bisnis MLM yang sudah mendapatkan klarifikasi dari pihak Majelis Ulama Indonesia (MUI) belum lama ini, bahwa yang di haramkan adalah bisnis jenis money game/pyramid.

Mudah-Mudahan tulisan ini dapat di jadikan bahan masukan bagi anda selaku bisnis MLM.Terimakasih .(Dewan Rahardjo, Oktober 2000). 
1. Bagaimana anda memandang bisnis Multi Marketing (MLM)?

Saya kira itu merupakan pendekatan baru dalam bidang marketing yang melibatkan konsumen langsung dengan insentif.Pembagian keuntungan didesentralisasi dan tidak terpusat.

2. Apa itu menguntungkan bagi konsumen?

Dalam pandangan Islam, apakah cara pemasaran itu baik?

Bagus saja, karena konsumen akan mengenal dan mempunyai hubungan langsung dengan komoditinya. Jadi tidak ada pemalsuan, (karena) konsumen bisa mengecek langsung.Kalua tidak, merekan 'kan nggak mau melakukan sistem pemasaran ini. Dan juga (dengan sistem ini ) sekaligus membentuk sosial dan mempereratnya.Tapi ada yang menyebut MLM sebagai bisnis orang Yahudi ah, tidak juga. Jangan langsung dihubungkan dengan orang Yahudi dan sebagainya, itu tidak ada hubungannya, hanya mencari-cari saja.

3. Bagaimana dengan teknik pemasaran , karan MLM mempunyai cara tersendiri memanfaatkan konsumen untuk ikut menjual?

Asal orang yang bersangkutan mau, tidak apa-apa.Kan ridak ada paksaan.

4. Apakah sistem pemasaran MLM tidak haram hukumnya dalam Islam? Kalua menurut saya tidak.

5. Bisnis yang melanggar agama seperti apa?

Seperti misalnya, tidak menepati janji, tidak menepati kesepakatan, atau merampas.Tapi saya misalnya ada penjualan obat, kosmetik.Obat dan kosmetik itu bagus sekali dan berhasil menjaring konsumen yang banyak.

\section{J. Pandangan Tokoh-Tokoh Islam Tentang Bisnis MLM}

1. Prof.Dr.H.M. Din Samyuddin.

Sekertaris Umum Majelis Ulama Indonesia (MUI), mengataan:

"yang haram,MONEY GAME".

"MLM haram jika tidak menjual produk"

2. Bismar Siregar, $\mathbf{S H}$.

3. Pengawas kode etik APLI, mengatakan: 
"Islam tidak mudah mengatakan haram".

"tanyalah Hati Nurani"

4. DR. Jalaludin Rahmat.

Cendikiawan Muslim, mengatakan:

"MLM tidak haram"

"kalua uang sebagai komoditi, itu yang haram".

\section{K. Cara Kerja Beberapa Bisnis MLM}

Berikut ini saya berikan bebrapa cara kerja yang sering dilakukan dalam perusahaan yang berbisnis MLM. Cara kerja ini say aulas untuk di jadikan bahan pertimbangan sebelum anda menggeluti sebuah bisnis MLM. Bahan pertimbangan ini bisa dilihat dari berbagai macam sudut.Yang saya ulas dalam bagian ini adala MLM yang memiliki produk atau jasa yang di perjual belikan.Dan yang menjadi pertanyaan mendasarnya adalah apakah kita betul-betul merupakan MLM yangmembagikan kenutungan dan mendapatkan keuntungan dari jual beli produk atau manipulasi sistim.

Secara umum, cara kerja dalam bisnis MLM adalah sebagai berikut:

1. Setiap orang akan mendapatakan ke untungan dari aktifitas jual beli yang di lakukannya. Jika dia inggin mendapatkan bonus yang lebih besar, maka dia bisa menggabungkan organisasi yang lebih besar pula.

2. Mereka ada di bawah, tetapi bisa membangun oraganisasi yang lebih besar daripada yang mengajukan, maka yang bersangkutan memiliki peluang untuk mendapatkan keuntungan yang lebih besar daripada orang yang mengajaknya di atas.

3. Jika pada priode tertentu seseorang mitra tidak melakukan pembelian produk, maka dia tidak akan mendapatkan keuntungan walaupun jalur di bawahnya menghasilkan omzet yang tidak terhingga.

4. Setiap orang yang bergabung di bisnis MLM dan ingin mendapatkan bonus yang lebih besar, maka dia harus berperan sebagai seller atau end-user dengan membeli sejumlah produk yang memenuhi syarat untuk mendapatkan bonus dan dia juga harus mensponsori orang lain agar terbentuk organisasi bisnis yang bisa menghasilkan omset. 


\section{Perbedaan MLM Syariah dengan MLM Konvensional.}

Secara sepintas MLM Syariah bisa saja tampak tidak berbeda dengan praktek-praktek bisnis MLM konvensional. Namun, kalua kita telah lebih jauh dalam proses oprasionalnya, ternyata ada beberapa perbedaan mendasar yang cukup signifikan antara kedua varian MLM tersebut.

Pertama, sebagai perusahaan yang beroprasi syariah, niat, konsep, dan praktek pengelolaannya senantiasa merujuk kepada Alqur'an dan Hadist Rasullulah SAW. Dan untuk itu struktur organisasi perusahaan organisasi perusahaan pun dilengkapi dengan Dewan pengawas Syariah (DPS) dari MUI untuk mengawasi jalannya perusahaan adar sesuai dengan prinsip-prinsip syariah Islam.

Kedua, usaha MLM Syariah pada umumnya memiliki visi dan misi yang menentukan kepada pembangunan ekonomi Nasional ( melalui penyediaan lapangan kerja, produk-produk kebutuhan sehari-hari dengan haraga terjangkau, dan pemberdayaan usaha kecil dan menengah di tanah air) demi meningkatkan kemakmuran, kesejahtraan, dan meninggikan martabat bangsa.

Ketiga, sistem pemberian insentif di susun dengan memperhatikan prinsip keadilan dan kesejahtraan. Di rancang semudah mungkin untuk di pahami dan di praktekkan. Selain itu, memberikan kesempatan kepada distributornya untuk memperoleh pendapatan soeptimal mungkim sesuai kemampuannya melalui penjuala, pengembangan jaringan, ataupun melalui keduanya.

Keempat, dalam hal marketing plan-nya, MLM Syariah pada umumnya mengusahakan untuk tidak membawa para distributornya pada suasana matrealisme dan konsumenrisme, yang jauh dari nilai-nilai Islam. Bagaimanapun, materialism dan konsumerisme pada akhirnya akan membawa kepada kemubaziran yang terlarang dalam Islam. 


\section{Hasil Wawancara}

Wawancara yang di lakukan oleh penulis adalah langsung melalui orang-orang yang di beri kuasa kuasa langsung oleh pihak P.T. Asuransi Allianz Life Indonesia cabang Manado untuk memberikan keterangan yang di butuhkan peneliti yang di jadikan bahan penyusunan penelitian peneliti.

Bapak. Faisal Hullah (Senior Bussiness Partner Allianz) memberikan penjelasan bahwa konsep Syariah di P.T. Asuransi Allianz Life Indonesia adalahh oleh peserta untuk peserta penanggungan di produk Syariah. Peserta atau nasabah dengan menerapkan iuran atas nama peserta, pengurus di Syariah adalah Allianz mendapatkan 25\% dari iuran ausransi atas nasabah (premi) yang dalam sistem Syariah di sebut Tahabarru',bukan dari premi yang di setor nasabah melainkan biyaya asuransi dari proposal sebagai ongkos capeknya Allianz mengelola uang nasabah dikenal dengan akad wakalah bil ujrah ( perwakilan berdasarkan fee) atau [Perwakilan penyerahan mandate dari pihak pertama (peserta) kepada pihak kedua ( perusahaan asuransi ) untuk melaksanakan kepentingan pihak pertama], atau tercantum di SPAJ dan polis asuransi. (Faisal Hullah, 24 Febrari 2014).

\section{N. Penutup}

Hubungan interaksi sesame manusia baik yang unduk kepaa syari'at atau pun yang keluar dari ketaatan kepadanya tidak terbatas.Setiap masa dan daerah terjadi berbagai bentuk dan modal interaksi sesama mereka yang berbeda dengan dan model interaksi pada masa dan daerah lainnya. Oleh karana itu bukan suatu hal yang bijak, jika hubungan interaksi antar sesama mereka di kekang dan di batasi dalam bentuk tertentu. Karena itulah dalam syari'at Islam tidak pernah ada dalil yang membatasi modal interaksi sesame mereka. Ini adalah suatu hal yang amat jelas dan di ketahui oleh setiap orang yang memahami syari'at Islam. Sebagai buktinya di dalam ilm Fiqih di kenal suatu kaedah besar, yaitu :

"Hukum asal dalam segala hal adalah boleh, hingga ada dalil yang menunjukan akan keharamanya" 
Kaedah itupun di dukung oleh dalil al-Quran dan Sunah Nabi Muhammad SAW di antaranya yaitu:

Dialah Allah yang menjadikan segala sesuatu yang ada di bumi untuk kamu dia berkehendak (menciptakan)mlangit, lalu di jadikan-nya tujuh langit. Dan dia maha mengetahui segala sesuatu.

Dan sabda Rasulullah SAW, yaitu:

Kalian lebih mengetahui urusan dunia kalian (HR.Muslim).

Asuransi syariah pada dasarnya merupakan cara dalam menghindari resiko yang akan di hadapinya. Mereka semua akan saling bekerja sama untuk menanggungnya dan sedkit pemberani derma (premi) yang di berikan oleh para peserta (nasabah). Yang memiliki arti memberikan perlindungan, ketenangan, rasa aman, dan bebas dari rasa takut.

Anggota dewan pengawas asuransi syariah, seha rusnya terdiri dari ahli syariah yang sedikit banyak menguasai hukum dagang positif dan cukup terbiasa dengan kontrak kontrak bisnis. Anggota dewan pengawas syariah tidak hanya memahami aspek syariah semata, akan tetapi juga harus memahami berbagai aspek perbankan, akutansi dan ekonomi.

\section{DAFTAR PUSTAKA}

AM. Hasan Ali, Asuransi Dalam Perspektif Hukum Islam (Jakarta: Kencana), 2004 AM. Hasan Ali, Asuransi Dalam Perspektif Hukum Islam, SuatuTinjawan Analisis Histori, Teoritis, dan Praktis( Jakarta: Prenada Media, 2004)

Abudin Nata, Paradigma Pendidikan Islam,( Jakarta: PT. Grasindo, 2001)

Dawam Raharjo, Wawancara dengan Majalah Hebat dan Sejahtera, Yang di Terbitkan Pada edisi Oktober Tahun 2000

Departemen Pendidikan Nasional, Kamus Besar Bahasa Indonesia, (Edisi III. Jakarta: Balai Pustakah, 2007) 
Dewan Pengawas Syari'ah dan Divisi Syasi'ah, Besic Trening Syari'ah, ( P.T. Asuransi Alianz Life Indonesia, 2013).

Faisal Hullah ( Senior Bussines Partner), Hasil Wawancara, 24 februari 2014

Gruenwald, G. 1985. Seri pemasaran dan promosi, pengembangan produk baru, PT Alex Media Komputindo, Jakarta

H. Buchari Alma dan Doni Juni Priansa, Menajemen Bisnis Syari'ah

( Bandung: Alfabeta: 2009)

Ibnu Sukantjo dan DH Swasta Drs, pengantar Ekonomi PerusahaanModeren,( Edisi Revisi: Yogyakarta: Liberti Yogyakarta, 1982)

Kamus Ilmiah Populer, ( Untuk SD, SMP, SMA dan Umum: Karya Ilmu Surabaya) Kamus Istilah, Menajemen, ( Inggris-Indonesia, Indonesia-Ingris: Bandung : CV Irma Widya, 2005)

Keegan, Warren J. 1996, Menajemen Pemasaran Global: Alih Bahasa, Alexsander Sindoro Jilid 1, ( Jakarta: Prenhalindo)

Lexi J. Moleong, Metode Penelitian Kwalitatif( Bandung: Remaja Rosadakarya, 2001)

Margono, Suyud, Kompilasi Hukum Ekonomi Syari'ah, Jakarta: Novindo Pustaka Mandiri, 2009

Michael j. Baker.Marketing, an Introductory Tex 6.( Edition. Palgrave. 19970

Moh. Nasir, Metode penelitian ( Jakarta : Graha Indonesia, 1999)

Monika Turangan (Admin), Hasil Wawancara, 02 Maret 2014 
Mohammad Nizarul Alim, Muhasabah Keuangan Syari'ah, (editor, Fahrur Mus'is. Solo Agwam 2011)

Muhamad Yasin Ali, SE., AK Teori Bisnis Asuransi Syariah, (jakarta: Kencana, 2002)

Nana Sudjana dan R Ibrahim, Penelitian dan Penilaian Pendidikan (Bandung Sinar Baru Algen Sind, 1989)

Nana S. Sukmadinata, Metode penelitian Pendidikan (Bandung : PT . Remaja Rosada Karya, 2006)

Nasution ,Metode penelitian Kualitatif, (Bandung : jemars, 1998)

Peraturan Menteri Perdagangan Republik Indonesia No. 13/M-DAG/PER/3/2006 tentang Ketentuan dan Tata Cara penerbitan Surat Izin Usahapenjualan langsung dengan memuat larangan tegas yang tercantum padabab VII. 